\title{
Diretrizes para autores
}

\author{
Guidelines for authors
}

Instrucciones para los autores

1. A contribuição deverá ser original e inédita e não poderá estar sendo avaliada para publicação em outra revista.

2. Os textos serão aceitos em português, espanhol, francês, italiano e inglês.

3. A titulação mínima para o proponente é de DOUTOR.

4. Os artigos enviados aos editores da revista História: Debates e Tendências serão submetidos à avaliação cega de no mínimo dois pareceristas.

5. Os textos deverão ser submetidos por meio do SEER, através do site.

6. A revista é composta pelas seções Dossiê, Artigos livres, Fontes comentadas, Entrevistas e Resenhas.

7. Provas: as provas para correção de erros na preparação da versão final para publicação serão enviadas ao autor correspondente e deverão ser devolvidas dentro de um prazo de 72 horas, por correio expresso ou eletrônico.

\section{Apresentação do texto}

Para efeito de padronização gráfica, os trabalhos deverão seguir, rigorosamente, as normas abaixo especificadas, sob o risco de não serem aceitos, independentemente da adequação do conteúdo.

Os artigos deverão ser originais e ter a seguinte estrutura: a) Título do trabalho: letras minúsculas nas iniciais do título, salvo palavras que exijam, pelas normas da língua portuguesa, o uso de letra maiúscula; b) Autoria: nome completo e e-mail dos autores (quando a autoria for de acadêmicos, a coautoria deverá ser do professor-orientador); c) Resumo/ Palavras-chave: com no mínimo 10 e no máximo 15 linhas, espaçamento entrelinhas simples, seguido de 3 a 5 palavras-chave; d) Abstract/Keywords: resumo e palavras-chave com título do artigo em língua estrangeira; f) Introdução; g) Desenvolvimento (subdivisões do texto); h) Considerações finais; i) Referências; j) Notas de fim, quando necessário. 
1. Os artigos deverão ter entre 25.000 e 45.000 caracteres com espaços, incluídas as notas e as referências; os textos para as seções de Resenhas, Fontes comentadas e Entrevistas deverão ter entre 12.000 e 14.000 caracteres com espaços, também incluídas as notas e as referências.

2. Os artigos deverão vir acompanhados de resumo no idioma original, e de um resumo em português, quando este não for o idioma original, bem como de resumos em espanhol e em inglês, de no máximo dez linhas, três palavras-chave no idioma original, em português (quando este não for o idioma original), três em inglês (keywords) e três em espanhol (palabras clave).

3. O título do artigo deverá aparecer em seu idioma original e traduzido para o português (quando este não for o idioma original) seguido de suas versões em inglês e espanhol.

4. Independentemente da seção em que se enquadrem, os textos deverão ser digitados no editor de texto Word for Windows em formato A4, fonte Times New Roman, tamanho 12 , espaçamento entrelinhas de 1,5 , margens de $2,5 \mathrm{~cm}$, parágrafo de $1,5 \mathrm{~cm}$ (primeira linha). Os subtítulos deverão ter fonte de tamanho 13, com alinhamento à esquerda, espaço simples, espaçamento de 6 pts antes e depois.

5. Resumo e Palavras-chave: o resumo deverá ser redigido em parágrafo único, frases concisas (não em tópicos), com verbos na voz ativa e na terceira pessoa do singular; as palavras-chave devem aparecer logo abaixo do resumo, separadas por ponto.

6. Ilustrações, tabelas e outros recursos visuais: deverão ter identificação completa (títulos - espaçamento simples, fonte 12, alinhamento justificado; legendas e fontes - espaçamento simples, fonte 10, alinhamento justificado) e ser numeradas consecutivamente, inseridas o mais próximo possível da primeira menção no texto. Por se tratar de publicação em preto e branco, recomenda-se, na elaboração de gráficos, uso de texturas no lugar de cores. Em caso de fotos ou ilustrações mais elaboradas, deverá ser enviado arquivo anexo com os originais. Tabelas e quadros deverão estar no formato de texto, não como figura. Imagens e/ou ilustrações deverão ser enviadas como "Documentos suplementares" em arquivo à parte, no formato JPEG ou TIF, em alta resolução (no mínimo 300dpi). O autor é responsável pela autorização de publicação da imagem bem como pelas referências correspondentes.

7. Siglas: na primeira vez em que forem mencionadas, devem, antes de constar entre parênteses, ser escritas por extenso, conforme exemplo: Universidade de Passo Fundo (UPF).

8. Notas: deverão ser utilizadas apenas as de caráter explicativo e/ou aditivo. Não serão aceitas notas de rodapé (converter em notas de fim).

9. Destaques: deverá ser usado itálico para palavras estrangeiras com emprego não convencional, neologismos e títulos de obras e periódicos.

10. Citações: deverão obedecer à forma (SOBRENOME DO AUTOR, ANO) ou (SOBRENOME DO AUTOR, ANO, p. xx). Diferentes títulos do mesmo autor, publicados no 
mesmo ano, deverão ser diferenciados adicionando-se uma letra depois da data (SOBRENOME DO AUTOR, ANOa) e (SOBRENOME DO AUTOR, ANOb). As citações com mais de três linhas deverão constar em novo parágrafo, em corpo 10, sem aspas, alinhamento justificado, margem esquerda de $2,5 \mathrm{~cm}$, sem deslocamento de primeira linha, com espaçamento simples e 6 pt antes e depois. Deverá ser adotado uso de aspas duplas para citações diretas no corpo do texto (trechos com até três linhas). No caso de mais de três autores, indicar sobrenome do primeiro seguido da expressão latina et al. (sem itálico). A referência reduzida deverá ser incluída após a citação, e não ao lado do nome do autor, conforme exemplo: De acordo com Freire (1987, p. 69), “[...] o educador problematizador (re)faz, constantemente, seu ato cognoscente, na cognoscitividade dos educandos" (1987, p. 69).

11. Referências: deverão constar, exclusivamente, os textos citados, em ordem alfabética pelo nome do autor, seguindo as normas da ABNT. Deverá ser adotado o mesmo padrão em todas as referências: logo após o sobrenome, que será grafado em caixa alta, apresentar o nome completo ou apenas as iniciais, sem misturar os dois tipos de registro (FREIRE, Paulo ou FREIRE, P.).

\section{Exemplos de referências mais recorrentes}

Livros:

SOBRENOME, Nome. Título do livro: subtítulo. Número de edição. Cidade: Editora, ano.

Capítulos de Livros:

SOBRENOME, Nome. Título do capítulo. In: SOBRENOME, Nome (Org.). Título do livro: subtítulo. Número de edição. Cidade: Editora, ano. p. xx-yy. (página inicial - final do capítulo).

Artigos em periódicos:

SOBRENOME, Nome. Título do artigo. Nome do Periódico, Cidade, v. e/ou ano (ex.: ano 1), n. , p. xx-yy (página inicial - final do artigo), mês abreviado. ano.

Textos de publicações em eventos:

SOBRENOME, Nome. Título. In: NOME DO EVENTO, número da edição do evento em arábico, ano em que o evento ocorreu, cidade de realização do evento. Tipo de publicação (anais, resumos, relatórios). Cidade: Editora, ano. p. xx-yy (página inicial - final do trabalho).

Dissertações / Teses:

SOBRENOME, Nome. Título da D/T: subtítulo. Ano. Número de folhas. Dissertação/Tese (Mestrado em.../ Doutorado em...) - Nome do Programa de Pós-Graduação ou Faculdade, Nome da IES, Cidade, Ano.

Sites:

AUTOR(ES). Título (da página, do programa, do serviço, etc.). Versão (se houver). Descrição física do meio. Disponível em: <http://...>. Acesso em: dd(dia). mês abreviado. aaaa(ano). 


\section{Condições para submissão}

Como parte do processo de submissão, os autores são obrigados a verificar a conformidade da submissão em relação a todos os itens listados a seguir. As submissões que não estiverem de acordo com as normas serão devolvidas aos autores.

1. A contribuição é original e inédita e não está sendo avaliada para publicação por outra revista; caso contrário, justificar em "Comentários ao Editor".

2. Os arquivos para submissão estão em formato Microsoft Word, OpenOffice ou RTF (desde que não ultrapasse os $5 \mathrm{MB}$ ).

Todos os endereços de URLs no texto (ex.: $\underline{\text { http://www.ibict.br) }}$ estão ativos e prontos para clicar.

O texto está em espaço 1,5; usa uma fonte de 12 pontos; emprega itálico ao invés de sublinhado (exceto em endereços URL); com figuras e tabelas inseridas no texto, e não em seu final.

O texto segue os padrões de estilo e requisitos bibliográficos descritos em Diretrizes para autores, na seção Sobre a Revista.

A identificação de autoria deste trabalho foi removida do arquivo e da opção Propriedades no Word, garantindo desta forma o critério de sigilo da revista, caso submetido para avaliação por pares.

\section{Declaração de Direito Autoral}

Autores que publicam nesta revista concordam com os termos que seguem.

- Autores mantêm os direitos autorais e concedem à revista o direito de primeira publicação, com o trabalho simultaneamente licenciado sob a Licença Creative Commons Attribution que permite o compartilhamento do trabalho com reconhecimento da autoria e publicação inicial nesta revista.

- Autores têm autorização para assumir contratos adicionais separadamente, para distribuição não-exclusiva da versão do trabalho publicada nesta revista (ex.: publicar em repositório institucional ou como capítulo de livro), com reconhecimento de autoria e publicação inicial nesta revista.

- Autores têm permissão e são estimulados a publicar e distribuir seu trabalho on-line (ex.: em repositórios institucionais ou na sua página pessoal) a qualquer ponto antes ou durante o processo editorial, já que isso pode gerar alterações produtivas bem como aumentar o impacto e a citação do trabalho publicado (Veja, O Efeito do Acesso Livre).

\section{Política de Privacidade}

Os nomes e os endereços informados nesta revista serão usados exclusivamente para os serviços prestados por esta publicação, não sendo disponibilizados para outras finalidades ou a terceiros. 